\title{
EMERGING TRENDS IN THE STUDY OF PROTEST AND SOCIAL MOVEMENTS
}

\author{
Pamela E. Oliver, Jorge Cadena-Roa \\ and Kelley D. Strawn
}

\begin{abstract}
Four important trends in the study of social movements are discussed: expanding the case base beyond the social reform movements of Europe and Anglo-America to encompass other regions and types of movement; a theoretical synthesis that integrates protest with institutional politics and focuses on mechanisms and processes rather than causes and effects; a growing focus on events as units of analysis; and increasing integration of social psychological and cultural theories of social construction with structuralist accounts of movements. Taken together, they promise theory that is both broader in scope and better able to address the diversity of social movements.
\end{abstract}

\section{INTRODUCTION}

Fifty years ago, sociologists considered protest to be an undemocratic intrusion into politics. In the wake of the movements of the 1960 s, protest is now seen as an important adjunct to democratic polities and a significant factor in the transition from authoritarian to democratic regimes. The study of protest and social movements has mushroomed from a marginalized and almost-dying sub-specialty of social psychology in the 1960 s to a large specialty area of

\section{Political Sociology for the 21st Century}

Research in Political Sociology, Volume 12, 213-244

(C) 2003 Published by Elsevier Science Ltd.

ISSN: 0895-9935/PII: S0895993503120098 
sociology in its own right with significant ties to political, organizational, and cultural sociology as well as to social psychology. Social movements theorists see protest as "politics by other means," and it is now well recognized that extra-institutional and institutional politics are intertwined and interdependent.

Since the 1970 s, scholars of social movements have developed a productive body of theory and research around the interrelated theoretical orientations generally labeled resource mobilization, political process, and framing theories. There are excellent reviews available of these theoretical traditions (e.g. Benford \& Snow 2000; McAdam, McCarthy \& Zald, 1996) and we cannot do justice to them here. Instead, our agenda is forward-looking, seeking to pick up several key trends in the study of social movements that we believe should be important in the coming decades. All involve transcending old categories and boundaries and all combine methodological and theoretical advances. Partisans view some of these trends as coming from theoretically incompatible standpoints, but we do not. Instead, we see them as addressing different important features of a complex reality. The field of social movements is broad, and no article of this length can possibly do justice to every significant trend. Even with our restricted scope, we have had to reduce or eliminate our coverage of some topics to meet the word limits of this piece. Despite these limits, we are confident that the trends we highlight are among the most important.

We treat the first two trends more briefly, and the other two in more detail. The first trend is that the case base underlying mainstream social movements theory is expanding beyond the reform movements of Anglo-America and Western Europe. Regionally, "general" theories are beginning to take account of Eastern Europe, Latin America, Asia, and Africa. Substantively, ethnic conflict, democratization movernents, and revolutions have been added to social reform movements as central topics of concern, and concepts of regime-movement relationships and the organization of protest have been broadened to encompass authoritarian regimes and the complex dependency relations of nations in the world economy.

This broader empirical base has fed into the second trend, a broad and unfinished attempt to rework the core theory of the relation between social movements and politics. Older theory focusing on the inputs and outputs of social movements as units of analysis is giving way to new theory which views movements as imperfectly bounded sets of processes and mechanisms capturing complex relations between movements and states.

Changing theory has been linked to the third trend, increased use of even analysis in social movement research. Analyses of the distributions of events have long been part of the repertoire of movement research, but their use is growing and has led to new research on the interrelations of different kinds of acts over time. We give special attention to methodological and theoretical issues that arise because new media are the major source of event data.

The fourth trend that needs to grow involves moving past the old structuralist versus constructionist debates, and an acceleration of the rapprochement between theories grounded in political sociology on the one hand and social psychology and cultural sociology on the other. This involves abandoning false dichotomies such as rational versus emotional, political versus psychological, material versus cultural and growing appreciation of the underlying unities. We offer what we believe are some important clarifications among concepts and levels of analysis in this area.

In selecting these trends, we have omitted many important lines of work. What unifies these is that they are parts of the general project of developing a broader, more dynamic and fluid conception of the terrain of movement processes. Protest event analysis and social constructionist theory may seem to be at opposite ends of a theoretical continuum - certainly specific research projects tend to work on one or the other, and specific researchers in one stream all too often disparage the work in the other - but any valid conception of social movements must be able to encompass both.

\section{EXPANDING THE CASE BASE}

All theories, no matter how abstractly stated, are grounded in empirical cases. Mainstream sociological social movement theory developed in the context of the reform movements of the U.S. and Western Europe, and this base shaped the theory. As Tilly (1978) argued long ago, the "social movement" as understood in the U.S. and Western Europe co-evolved with relatively stable popular democracies. Regimes vary greatly in their popular legitimacy, stability, readiness to repress, and responsiveness to popular mobilization as well as in their capacity to contain and channel inter-group conflicts within the nation-state. These matter even in comparing European nations, but the range of variation is severely truncated when only the dominant industrial nations of U.S. and Western Europe are considered. Regimes elsewhere are generally less stable or less democratic, or both. Cases from other regions highlight the limitations of prior theory, and point to new problems to study.

The democratization wave of the 1990 s opened a new range of research about the form and role of protest moverments and their relations to regimes in authoritarian and post-authoritarian conditions (e.g. Alvarez, Dagnino \& Escobar, 1998; Cook, 1996; Escobar, 1992; Escobar \& Alvarez, 1992; Foweraker, 1995; Foweraker \& Craig, 1990; Hipsher, 1996, 1998a, b; Mainwaring, 1987, 1989; Mainwaring \& 
Viola 1984; Oxhorn, 1995; Sandoval, 1998; Schneider, 1995; Stokes, 1995). Linz and Stepan's (1996) detailed comparative investigations of democratizing states have identified the ways in which the specific character of the authoritarian state as well as the timing and sequence of reforms have shaped the trajectory of democratization as well as ethnic conflicts and other social turmoil. Protest and social movements play crucial roles in these processes and are affected by them.

Movements in nations that are not dominant in the world economy have different configurations arising from their economic dependency, including severe material deprivation among large segments of the population and the strictures of austerity programs. A separate literature has focused narrowly on protests directed at austerity programs and neoliberal reforms (Walton, 1989; Walton \& Ragin, 1990; Walton \& Seddon, 1994; Williams, 1996) and, in a very limited way, on collective protest following austerity (Auvinen, 1996, 1997), but these have done little to integrate regional distinctions and unique national contexts into the broader realm of social movements theory.

A growing literature examines international and transnational movements and issue networks as well, with special emphasis on how these formations relate to and affect national politics and movements. Space does not permit a review of this work, but see Smith, Chatfield and Pagnucco (1997), Keck and Sikkink (1998), or Guidry, Kennedy and Zald (2000) for reviews.

Until recently, there has been little sustained attempt to bring mainstream social movement theory into dialogue with experiences outside Anglo-America and Europe. Scholars of movements in other regions largely ignored or found wanting general social movement theory in addressing the movements of their regions, and "meneral social movement theory in addressing the movements of their regions, and formulating their theories. Even as late as 1996, a major conference volume edited by McAdam, McCarthy and Zald titled Comparative Perspectives on Social Movements treated only cases from the U.S. and Europe (although there were a couple of Eastern European cases) and appeared not even to mention Africa, Latin America, or Asia. By contrast, McAdam, Tarrow and Tilly's (2001) most recent theoretical synthesis includes cases from Mexico, Kenya, the Philippines, India, and China in addition to those from Europe.

While the body of work for Asia and Africa has grown of late, the most sustained dialogue so far between "regional" studies and "mainstream" theory has centered on Latin American movements. Latin American universities have a long tradition of scholarship with respect to social movements and collective action in their own countries. Beginning in the late 1980 s, several edited volumes critically juxtaposed Latin American traditions and those of U.S./European social movements theory, seeking to develop an understanding of popular protest that started with the Latin American experience (Eckstein, 1989; Escobar \& Alvarez, 1992; Jaquette, 1994
Jelin, Zammit \& Thomson, 1990). The articles in these volumes address a broad and eclectic range of collective action topics including peasant and grassroots organizations, violence and revolutionary protest, women's organizations and their role in local community movements and broader identity issues, democratization, the role of the Catholic Church in mobilization, and the utility of the "new social movements" framework in Latin America.

Subsequent Latin American work has engaged many of the major theoretical issues in the study of movements. Following trends elsewhere in the field, women/feminism/gender topics have become quite prominent in Latin American research. A number of these have focused on the conflicts within women's movements internationally and the prospects for bridging these gaps (Ehrick 1998; Guy, 1998; Safa, 1996). Some have engaged broader contemporary topics like feminism, identity, and democracy (Huiskamp, 2000), gender and citizenship (Schild, 1997), and how gender shapes political protest (Einwohner, Hollander \& Olson, 2000), while others address much more localized problematics, like the role of women in the rise of urban movements (Massolo, 1999).

Recent work has also engaged important topics relating to culture, identity, and "new social movements" in the Latin American context. Projects have sought to link identity formation and its relationship to violence and citizenship (Schneider, 2000), democratization and regime change (Huiskamp, 2000), and class relations (Veltmeyer, 1997). The relevance of social movements in the context of civi society is also a recurrent theme. Alvarez, Dagnino and Escobar (1998) draw on contemporary civil society paradigms to argue that the rise in democratization in Latin America has not diminished the significance of social movements. At the same time, Beasley-Murray (1999) argues that the civil society paradigm does not adequately account for the rapid rise of religious fundamentalist movements in Latin America. Still others have argued that culture and civil society are essential dimensions for understanding increased regional integration as a product of neo-liberalism (Jelin, 2001), and that mobilization in the Latin American context must be theorized by integrating "new social movement" concepts with more conventional resource and organizational elements (Mascott, 1997; Zamorano Farías, 1999).

The contemporary work focusing on the unique mobilization experience of Latin America addresses a number of additional topics. The role of the Catholic Church in grassroots mobilization remains a topic of interest (López Jiménez, 1996), while the spread of evangelical and fundamentalist religious organizations throughout Latin America has received considerable attention, particularly with respect to how these relate to indigenous and community movements (Canessa, 2000; Le Bot, 1999) and their relation to social changes brought about by economic crises and neo-liberal policies (Gill, 1999; Misztal \& Shupe, 1998). Other areas of 
focus have been land reform, peasant movements, and the unemployed (Kay, 1998; Larroa Torres, 1997; Petras \& Veltmeyer, 2001), the convergence of environmental awareness and social mobilization (Dwivedi, 2001; Stonich \& Bailey, 2000) urban movements and community/neighborhood organization (Ellner, 1999; Fernandez Soriano, Dilla Alfonso \& Castro Flores, 1999), the transnationalization of mobilization (Mato, 2000; Stonich \& Bailey, 2000), and regional integration and liberalization (Brysk \& Wise, 1997; Jelin, 2001)

\section{PROTEST AND POLITICS: FROM OUTCOMES TO CONSEQUENCES}

The growing case base has fed into a broadening and reworking of theory. The political process synthesis knits together political opportunities, framing and mobilization structures as an integrated account of the sources of social protest (McAdam, McCarthy \& Zald, 1996). As useful as this synthesis has been, there is a growing belief that it is too static and categorical, with its focus on inputs and outputs between movements and regimes as distinct actors (Goldstone, 1998). There are growing attempts to theorize the dynamic interplay and interconnection between movements, parties, regimes and other actors as social change unfolds (Goldstone, 2002). McAdam, Tarrow and Tilly (2001) have called for a conceptual shift, away from looking for invariant causes and effects to looking for mechanisms and processes that occur in many different kinds of movements and that lead to different outcomes depending on the specific contexts within which they occur Metatheoretically, this involves a shift away from physics as a model, with its mechanical inputs and outputs. Oliver and Myers (2003a) and Koopmans (2002) suggest that population biology and evolution provide a different meta-theoretical model: in evolution, the same mechanisms and processes (e.g. mutation, differential fertility and mortality, environmental pressure) generate widely differen outcomes. Biologists can study the common features of these mechanisms and processes, the bounds they put on what is possible, and at the same time they recognize how these commonalities act to generate extreme diversity in species.

One aspect of this theoretical shift is to reframe old debates about movemen "outcomes" and the relation between movements and regimes. Early resource mobilization/political process research viewed outcomes in relatively simple ways. Tilly's polity model (1978) viewed movements as "challengers" who lack routine access to decision-makers. Once they succeed, they become polity members with routine access to decision making. Gamson $(1975,1990)$ refined this to two-dimensional typology: being accepted as a member of the polity (i.e. as having institutional access), and gaining new advantages (i.e. as achieving policy goals) Analytic reviews of studies of movement success may be found in Giugni (1998) and Burstein, Einwohner and Hollander (1995). Recent work has moved beyond the dichotomy of "success" and "failure" or even the idea of "outcomes" with its connotations of intentionality, and is instead considering "consequences." Actions can have wide-ranging and unintended consequences. One line of work picks up on the expansion of the case base, and expands the conception of how movements might affect regimes. Giugni (1998) distinguishes among incorporation, transformation and democratization. Incorporation occurs when movements or part of them are absorbed into the polity or into the existing institutional arrangements and procedures of society without altering the basic rules of the game. This path may lead to institutionalization, when movements become part of routine politics, or preemption when movement demands are integrated into governmental policy or legislation without opening the polity. Transformation requires fundamental changes in the social and political structures and institutions of society due to transfers of power that alter extant power relations within society. Revolutions are the most radical form of transformation, but movements often produce institutional change that alters power relations in a non-revolutionary way. Some of these transformations relate to transitions from authoritarian rule. Democratization develops when a transfer of power modifies the mutual rights and obligations between states and its citizens. Incorporation, transformation and democratization are not mutually exclusive processes but ideal types. Democratization presupposes at least some degree of incorporation and transformation.

New theorizing focuses on the dynamic interactions between regimes and movements. There is a growing recognition that movements and regimes change together or "comevolve" (Koopmans, 2002; Oliver \& Myers, 2003a). One pattern has been shifting tactics of social control of protests. Instead of battling protesters in the streets, police agencies increasingly turned to processes of channeling and negotiation to blunt the disruptive force of protests while allowing protesters to have their say (della Porta, 1996, 1999; della Porta \& Reiter, 1998; McCarthy, McPhail, Smith \& Crishock, 1998; McPhail, Schweingruber \& McCarthy, 1998; Rasler, 1996). Movements, in turn, have evolved in response to shifting police practices. Protests in the U.S. became more routine and less disruptive in the 1980 s and 1990s (Oliver \& Myers, 1999). As the mutual evolution and adaptation continued, the late 1990s saw the growth of a new generation of disruptive protesters who sought ways to evade police channeling and increase the disruption of their events (Smith, 2001)

In addition to broadening the conception of political outcomes, scholars increasingly recognize the importance of broader patterns of change in culture, opinions, and lifestyles. An early voice in this shift was Gusfield (1981), who 
talked about "linear" and "nonlinear" conceptions of social movements, and stressed that movements could have many diffuse consequences that go far beyond the question of whether a particular goal has been attained. Oliver (1989) similarly envisioned a way of thinking about social movements as chains of action and reaction. Most scholars working in the field have long since recognized that movements have byproducts and unintended consequences (e.g. Deng, 1997; Giugni, 1999), and that "success" or "failure" hardly describe most of a movement's effects (Tilly, 1999, p. 268). Other kinds of consequences include movement spillover effects (McAdam, 1988; Meyer \& Whittier, 1994) in which one social movement inspires, influences, and provides personnel to other movements and effects on the subsequent personal life trajectories of activists; changes in public discussion (della Porta, 1999; Koopmans \& Statham, 1999; Melucci \& Lyyra, 1998); changes in the public definition of social issues (Gusfield, 1981); collective identity of social groups (Taylor \& Whittier, 1992); and changes of meaning in everyday life (Melucci, 1985).

\section{PROTEST EVENT ANALYSIS}

As theory has increasingly recognized the importance of ongoing strategic dynamics and mutual adaptation to understanding social movements, new theoretical and methodological tools are required to support this theory. One of the most important has been a growing emphasis on events rather than organizations or movements as units of analysis. Sewell (1996) argues for an emphasis on events in qualitative historical research, and this is likely to be a productive avenue for more qualitative research. However, most event-oriented studies have been quantitative. Quantitative studies of protest event time series have long had a place in the study of social movements, including for example Tilly (1995), McAdam (1982), and Koopmans (1993), and it has long been recognized that focusing only on organizations missed important non-organizational (or hidden organizational) sources of collective action (Oliver, 1989). The growth of the quantitative analysis of protest accelerated with the application of event history analysis by Susan Olzak (1987, 1989, 1992), Sarah Soule (1997, 1999; Soule, McAdam, McCarthy \& Su, 1999; Soule \& Zylan, 1997), Myers (1997, 2000; Myers \& Buoye, 2001) and others. Analysis of quantitative event series has allowed for more specific testing of hypotheses about the workings of the different elements of the political process models.

Event analysis is especially appropriate for the new directions of theorizing for several reasons. First, events are (at least potentially) commensurate across different kinds of movements, thus facilitating unified theory of mobilization.
There do remain important questions about what to count as an "event," and there is no consensus on some single definition of what a protest event is. ${ }^{1}$ The majority opinion favors "minimalist" definitions for data collection that includes a very broad range of events, with factors such as size or disruptiveness incorporated as control variables in analyses. Second, event-centered analysis readily incorporates time dynamics and mutual causality. The actions of challengers and regimes can be treated as mutually causative over time, and covariates can also vary over time. Analyses can move beyond a focus on single movement organizations or issues and into the realm of quantitative modeling of protest as a more generalized social phenomenon.

Third, an events approach can handle mobilization failure and decline, as well as its rise. It avoids the problem of sampling on the dependent variable, i.e. of only researching instances in which mobilization succeeded, because it is possible to identify the predictors or consequences of protest not occurring (or of occurring at a low rate). This promises to contribute to a much more sophisticated understanding of broader mobilization dynamics. Finally, an events approach permits study of the ways in which events affect other events (Oliver, 1989) through innovation (McAdam, 1983), diffusion (Myers, 2000; Olzak, 1987, 1989; Soule, 1997), and adaptive learning (Macy, 1990).

These advantages of event-centered analysis have led some to predict that events will lead to a unification of collective action theory and research. In particular, it is a source of optimism for those who contend that the broader field of collective action theory has been long on theory in recent decades but short on empirical evidence (Koopmans \& Rucht, 1999). ${ }^{2}$ But there are also cautions. While acknowledging the value of event analyses, Tarrow (1998) warns that there is substantial historical variation in the ways that political events, political processes, and political opportunities interrupt the "normal" flow of events over time.

Event-based research provides new data that feed theory development. Fillieule (1998) examines the national "protest thythmology" of France in the 1980s, while Oliver and Myers (1999) show similar thythms for a U.S. city in the 1990s. Rucht's (1996) analysis of right-wing radicalism in Germany shows that its decline after the peak in 1991 and 1992 was tied to the emergence of counter-movements and the reaction of key political actors and the state. Gentile (1998) shows that radical right parties and xenophobic organizations and protest rose together in Switzerland (1984-1993), even though neither sought alliance with or entry into the other.

Event data are not limited to Western countries where democracy is already institutionalized. Examining the post-communist countries of the Slovak Republic, Slovenia, and Hungary, Szabo (1996) argues that political protest is central in processes of regime change and the consolidation of new systems, and finds that the majority of protest forms are familiar (marches, rallies, strikes, etc.), but new 
protest forms are emerging as post-communist regimes consolidate. Ekiert and Kubik (1998) treat collective protest as a measure of democratic consolidation in Poland between 1989 and 1993, concluding that protest was "economy-centered" and came from predominantly mainstream groups, suggesting that Polish democracy had yet to accommodate protest as a "complement" to other institutions of representation. Within a similar context of transition from communist authoritarian rule to republican state structures, Beissinger (1998) examines the four-year protest wave that characterized the state-formation experience of former Soviet countries. Through event analysis, Beissinger is able to demonstrate how, contrary to conventional interpretations, the apparent increase in violent protest over the period was not a general characteristic, but rather one attributable almos exclusively to conflict over the definition of new political boundaries that were slower to emerge. Mueller (1999) uses event data to critique Western-derived models of protest cycles. Drawing on the 1989 protest cycle in the former East Germany, she argues models derived from Tarrow's analysis of Italian protest cycles lack fit in the non-Western, "distintegrating Leninist regime" case.

Events analysis also permits deliberate operationalization and testing of specific premises of mainstream social movements theory. A number of studies test hypotheses about the relation between protest and opportunity structures. Soule et al. (1999) examine the mutual causal effects of Congressional opportunity structures and women's movement protest, finding that political events affect protests but that protests have no effect on outcomes. Kerbo and Shaffer (1992) analyze unemployment protests from 1890 to 1940 and argue that elite statements recognizing unemployment as an issue and supporting welfare programs represented a moment of substantially broader opportunity for the unemployed to act and that this accounted for the higher level of protest in the early $1930 \mathrm{~s}$ compared to 1890-1900. McCammon, Campbell, Granberg and Mowery (2001) argue for broader view of opportunity structures that is not restricted to the state, and show that the successes of state-level women's suffrage movements (1866-1919) were affected by prior changes in "gendered opportunities" i.e. expectations abou women's roles in political participation, in addition to more conventional politica opportunities and resources.

Event-centered analysis has addressed the claim that "new social movements (NSMs)" in Europe are qualitatively different from those in the United States (Kriesi, Koopmans, Duyvendak \& Giugni, 1995). Koopmans (1996) argues against the claim that NSMs have always reoriented what he calls "patterns of extraparliamentary political participation" in Europe. Analysis of protest events suggest that, contrary to the claim of NSM theorists, only in some countries does protes succeed in shifting claims away from traditional conflicts. Kriesi, Koopmans Duyvendak and Giugni (1992) identify two dimensions of state structure which affect political opportunities: (1) strength, or ability to impose outputs; and (2) the extent to which states are "exclusive" (repressive, confrontative, polarizing) versus "integrative" (facilitative, cooperative, assimilative). They show that movement outcomes varied across this $2 \times 2$ typology and that the new social movements are just as affected by these structures as other movements. Moreover, the typology is consistent with an "opportunity structures" argument.

There has also been event-centered hypothesis testing outside the industrialized regions of the U.S. and Europe. In two studies of Palestinian protest events in the West Bank between 1976 and 1985 , Khawaja $(1994,1995)$ uses parametric event history models to test resource mobilization, modernization, and deprivation theories with respect to mobilization. These studies find that each theoretical perspective, when tested alone, has at least some predictive power. However, when modeled together, only the resource variables retain their explanatory power, supporting resource mobilization theory. Walton and his collaborators (Walton, 1989; Walton \& Ragin, 1990; Walton \& Seddon, 1994) focus specifically on protest events directed against "liberalization" economic reforms in countries that are forced to renegotiate their foreign debt obligations with the International Monetary Fund, the World Bank, and other international actors (like the U.S. and Europe). With varying emphasis, these works test relative deprivation, resource mobilization, and world-systems/dependency explanations of the occurrence of protest events, finding some support for resource mobilization and world system theories.

\section{Events and News Media Data}

Most event data comes from newspapers or other news archives. For this reason, a correct understanding of the news media is a major methodological and theoretical priority for events researchers. The "selection bias" problem involves assessing the extent to which news sources represent some "true" account of the underlying protest events. Prior to the $1970 \mathrm{~s}$, analytical understanding of media bias was limited to what Mueller (1997) calls "representational" approaches, which simply held, without evidence, that the most prominent sources in use (the New York Times and the World Handbook of Political and Social Indicators) were the best available representations of protest. Some still argue for an essentially representational approach on the grounds that selection bias can be assumed to be relatively constant or systematic and will not significantly alter the results of research focused on analytical questions (see Koopmans, 1998). Beginning in the 1970 s, however, most discussion has focused on "media model" approaches (Mueller, 1997), beginning with Danzger (1975), who argued that contextual factors conditioned whether 
conflicts got reported in the New York Times, and Snyder and Kelly (1977) who followed this with a "functional model" that held coverage to be a product of even "intensity" and media "sensitivity." Efforts that followed these sought to define which dimensions of bias were most important and to address ways of controlling bias (see Franzosi, 1987; Jackman \& Boyd, 1979; Rucht \& Ohlemacher, 1992 among others)

McCarthy, McPhail and Smith (1996) refocused selection bias debates by using official police permit records of protests in Washington, DC, in 1982 and 1991 to identify a "population" of protest events against which media reports could be compared. In line with Snyder and Kelly, they found clear evidence of selection bias, and concluded that event size was the most important factor in determining if events got covered. Additionally, they found that some event forms were less likely to be covered (notably vigils) and that the amount of news coverage an issue had been receiving predicted the probability that a protest about it would be covered.

Two subsequent research projects that also assessed news sources against police records deepened the theoretical conception of the problem. Hocke (1998) draws on the much broader ProDat data collection project (Rucht \& Neidhardt, 1998) to develop an analysis of how a composite "news value" scale determines which events in Freiburg, Germany, get news coverage and those that do not. Consistent with McCarthy et al. (1996), Hocke finds that events with a higher news value score were more likely to get local news coverage, and more likely to be reflected in national news sources. However, his strategy of summing all "news value" elements into one composite scale prevented analysis of the relative importance of the individual factors. Oliver and her associates compared local event coverage in Madison, Wisconsin to police records of both permitted and unpermitted protests. They first assessed the coverage of protests as compared to other kinds of public collective events (Oliver \& Myers, 1999) and then focused more narrowly on what they call message events and their relation to institutional politics (Oliver \& Maney, 2000). In their data, the probability that a protest gets news coverage varies significantly from year to year, and is clearly associated with political and electoral cycles. Notably, the variation was large enough to make it appear that protest had declined in a year when it had actually increased. There were also complex interactions protests tied to institutional politics that were substantially more likely to be covered than other protests, but institutional politics competed with protest for space in the "news hole" so that both kinds of protests were less likely to be covered when the legislature was in session. They argue for theorizing the "tripartite" relations among protest, politics, and news media.

McCarthy, Smith and their associates have used their Washington, DC, data to examine media description bias (McCarthy et al, 1998; Smith, 2001). They show how the media covers "hard" and "soft" details about protest events, as well as how electronic and print media represent each of these differently. They find that hard news, when reported, is largely reported accurately by both media. However on soft news factors, electronic representations tend to be much more "thematic," emphasizing the purpose and significance of an event, while print media tend to be more "episodic," with greater coverage of protestor goals and details of the event.

McPhail, Schweingruber and McCarthy (1998) provide a detailed and rigorous examination of description bias of the 1995 March for Life, held in Washington, DC. While the complexity of the data definition and collection process precludes an elaboration of it here, of note is that the investigators were able to define, create, and test a set of variables to measure description bias, and to implement this schema in a real setting. Examining both television and newspaper reports on the event, they found that only a small portion of event coverage was given to describing the collective action, that those elementary descriptions were indeed details that coders had recorded, and that what was described were the behaviors most prevalent as reflected in the collected data. With this project, the investigators were able to establish an initial framework for examining description bias, and one that will undoubtedly be useful for future refinement of the issue.

These studies are just the beginning of what needs to be done. Maney and Oliver (2001) use newspaper data to assess police records and discuss the factors that affect whether police will record an event. They argue that no source can be treated as an unproblematic record of events, and that all sources must be cross-validated against other sources. There is a growing recognition that multiple sources are preferable to any single source, and that claims for the comprehensiveness of any source cannot be accepted without cross-validation by comparison with other sources. Oliver and Myers (2003b) call for modeling the creation of event records as a necessary underpinning of events research.

\section{INTEGRATING STRUCTURAL AND CONSTRUCTIONIST THEORIES}

Simultaneous with the rise of quantitative event studies has been a quite different trend, the rise of social constructionist theories of social movements. Although constructionist theories are usually framed as opposed to structuralist accounts, there is a growing appreciation for the need to integrate structural political theories of movements with constructivist theories rooted in social psychology and cultural sociology. Within sociology, the study of social movements has long stood at the intersection of political sociology and social psychology. The rise of new social movements and new social movements theory coincided and comingled 
with the rise of cultural sociology. Different intellectual traditions and political sensibilities have led to oppositions formed around false dichotomies: politics versus social psychology, rationality versus emotion, social structure versus social construction, resources versus culture, interests versus frames. At stake in these false dichotomies are images of the fundamental character of people in and around social movements, and the ways in which they interact with the social, political, and economic structures around them.

The "young Turks" of resource mobilization in the 1970s disparaged prior theories which attempted to explain the massive social movements of the 1960 s from individual psychologies or hidden Freudian motives, and argued that people's stated reasons for protesting could be taken at face value, that protesters were no less rational than the people they were protesting against. ${ }^{3}$ The capacity to mobilize could not be taken for granted, and resources and opportunities were critical. Focusing on structural factors rather than individual psychologies, resource mobilization theorists tended uncritically to assume a rational action model of individual choices. With the inevitability of academic cycles and some poetic justice, they in their turn were criticized by the next generation as imagining that people are nothing more than unthinking unemotional puppets of their material conditions. Although rational action theory is grounded in subjective expected utility theory, which treats interests as subjective, and there were clear recognitions by resource mobilization writers that grievances could be and were constructed, the attention of resource mobilization and then political opportunity theorists was focused on the constraints of structure and the problems of organizing, not on issues of social construction.

But movements not only develop rational and strategic actions, they continuously draw from cultural memories and repertoires, from values and moral principles to redefine situations, events, and relations in ways that would legitimate action, sanction inaction, gain bystanders' sympathy, reduce governments' ability to use social control resources, and attract media attention to reach distant publics. Movement actors try to appeal not only to audiences' reason or self-interest, but also to their values and normative judgment. They attempt to redefine what is going on and why. Social movements are not only mobilizations of protesters, displays of force, and threats of disruption of public order. Movements also have moral and cultural dimensions that involve insurgents' and publics' consciousness, beliefs, and practices.

The social-constructionist perspective can be summarized in terms of what Merton (1948) called a theorem basic to the social sciences: "If men define situations as real, they are real in their consequences" (Thomas \& Thomas, 1928, p. 572). There is no single way in which people go about defining situations and attributing meaning to things and relations. Analytically, this process involves psychological, social-psychological and cultural dimensions and processes. These dimensions interact with resources, opportunities and strategies in a relational, conflictual and open-ended way.

Social constructionist theories take as problematic both the way a given structural situation is defined and experienced and the meanings that will be attached to actions. Just as the structuralists tended to ignore construction processes, the constructionists have not generally theorized the ways in which material conditions constrain meaning-making processes. Social-constructionist orientations in social movements are broadly organized around four concepts: framing, identity, culture and emotions. The practitioners within each tradition are working on different central problems with different core insights and methodologies. Social psychological perspectives that examine how individuals make meaning in social contexts work differently from cultural perspectives that examine how meanings are made at a societal level. Social psychological and cultural perspectives are present to varying degrees in work organized around each of these concepts, and a failure to distinguish the social psychological and cultural levels of analysis has contributed to some confusion in all of them.

\section{Framing}

In the early 1980 s, a number of social movement scholars with social psychology backgrounds called for attention to cognitive and ideational factors such as interpretation, symbolization, and meaning. ${ }^{4}$ Particularly influential has been the concept of strategic framing of grievances elaborated by Snow and Benford (Snow \& Benford, 1988, 1992; Snow, Rochford, Worden \& Benford, 1986) who redirected attention to "subjective" dimensions in the analysis of social movements. They make the point that grievances are a matter of differential interpretation and that variation in their interpretation across individuals, social movement organizations (SMOs), and time can affect whether and how they are acted upon. Thus, the link between intensely felt grievances and susceptibility to movement participation is not immediate or necessary - between grievances and action lies interpretation. They argue that actors "often misunderstand or experience considerable doubt or confusion about what it is that is going on and why" (Snow et al., 1986, p. 466). Framing concepts enable us to examine empirically the process through which a given objective situation is defined and experienced. Framing a situation in a new way, adopting an injustice frame, for example, may lead people to consider what was previously seen as an unfortunate but tolerable situation as inexcusable, unjust or immoral. For action to occur, injustice frames should be accompanied by shifts in attributional orientation that shift blame or responsibility from self to system. 
Framing denotes "an active, process-derived phenomenon that implies agency and contention at the level of reality construction" (Snow \& Benford, 1992, p. 136). Thus, mobilization depends not only on the existence of structural strain, availability and deployment of tangible resources, opening or closing of political opportunities, and a cost-benefit calculus, but also on the way these variables are framed and the degree to which they resonate with targets of mobilization (Snow \& Benford, 1988, p. 213).

Although beginning with the social psychological concern with how individuals interpret events, framing theorists also viewed frames in cultural terms. Social movements are conceived of as producers of meaning and functioning as signifying agents (Snow \& Benford, 1992, p. 151). Movement activists are seen as strategic actors, consciously seeking to draw on old frames or create new ones which will resonate with their targets and enhance movement mobilization or goal-attainment. Their ability to do this is constrained by the cultural meanings their audience brings to the interaction. Accordingly, movements play an active role in cultural change by challenging mainstream meanings. For reviews of framing theory and research, along with some criticisms, see Benford (1997) and Benford and Snow (2000).

Framing theory has become almost fully integrated into the political process synthesis. Standard political process theory explications routinely devote sections to framing processes (e.g. McAdam et al., 1996) and it is well recognized that movement frames affect resources and opportunities. Recent concerns have been raised that framing concepts have been spread too broadly to encompass problems that are better treated with the concept of "ideology" (Oliver \& Johnston, 2000) or "discourse" (Ferree \& Merrill, 2000). As the serious engagement with the construction of movement ideas proceeds, we expect to see more overt theorizing of ideologies and discourses, in addition to frames, and their relation to political processes.

\section{Culture}

What accounts for frame resonance? According to Snow and Benford (1992, p. 140), the degree of frame resonance is attributed to the degree of fit between framings and the "life world of adherents and constituents as well as bystanders." But their analysis does not go any further into the causes of "resonance." A cultural approach is needed to address this question. How does culture matter in accounting for the origins, trajectories and outcomes of social movements? Under what conditions is culture a constraint or facilitator of social movements? Under what circumstances does culture inspire or impede collective action? The answer to these questions depends on how we understand culture.
In the last two decades, we have observed what Sewell (1999, p. 36) considers an "academic culture mania" set in several disciplines and sub-disciplines that have produced numerous definitions and operationalizations of the concept of culture. Following Sewell, there are two fundamentally distinct meanings of the term culture. The first is a theoretical category: culture (in the singular) is contrasted with some other abstract category of social life that is not culture, such as economy, politics or biology. In this sense, culture is a realm of social life defined in contrast to some other non-cultural realm or realms. The second meaning is a concrete, bounded body of beliefs and practices associated to an identifiable society or social group. In this sense, scholars talk of cultures (in plural) as distinct worlds of meaning.

In the first sense culture is used to mean that social processes are not the mere results of political, economic or social structures. This challenges dichotomous conceptions - such as culture versus structure, cultural versus instrumental rationality, cultural versus political goals of social movements - that usually emphasize the second part of the duality at the cost of the analysis of their interaction, or at least a more careful analysis of cultural dimensions (Alvarez et al., 1998). For reviews see Polletta (1997) and McAdam (1994).

In the second sense, culture stands for the symbols and signs whose meaning has a generalized status, provides categories for understanding, relates and sorts elements of social life in hierarchical orders, as well as mediates between and blends with structure and action (Alexander \& Smith, 1993; Alexander, Smith \& Sherwood, 1993; Sewell, 1999). The meanings attached to signs and symbols are subject to contention and reinterpretation. The bounded sets of differences between the meanings of signs and symbols that stand for things and relations in social life constitute cultures (plural). Thus, cultures in this sense allow us to identify and pin down specific meanings a given society or social group attributes to things and social relations and analyze how they favor or constrain social movements and their practices at different points of its life-course.

Thus, culture is not a set of independent variables that affect certain dependent variables. Most movement dimensions can be reinterpreted from a culturalist point of view. Movements have their origins and are shaped within dominant cultures (Morris, 1984). Movements challenge dominant meanings thus transforming mainstream culture and institutions (Baierle, 1998). Movements create their own culture that may facilitate or impede mobilization, resistance, recruitment and solidarity (Fine, 1985; Scott, 1990). Movements construct ends of action within cultural templates (Rubin, 1998). Movements find means ("tools") for action from host cultures (Swidler, 1986). Movements perform and produce culture through the symbols they create and the public behavior of their members (Fantasia \& Hirsh, 1995; Hunt, 1984). Movements produce cultural goods in the form of 
narratives, texts and myths (Fine, 1995). States may appropriate popular culture to create a mass base for politics (Mosse, 1975).

\section{Identities}

Identity is one of the most important and most confounded concepts in the study of social movements. "New social movements" theory argued that creating and maintaining identities had become the central purpose of "new" movements. Johnston, Laraña and Gusfield (1994) seek to bring some order to this confusion by distinguishing among individual identities, collective identities, and public identities. In brief, individual identities concern what people think about themselves, collective identities concern what groups think about themselves, and public identities concern how groups are viewed in a wider public discourse. Social psychology and symbolic interaction traditions treat individual identities, and the way they are formed in social interaction with other people and cultural representations. Cultural sociology treats public identities, and the way they are constructed through discourse. Groups' collective definitions of the meaning and purpose of the group (collective identities, narrowly defined) bring together social psychological and cultural processes. Unfortunately, their clarifications seem to have been ignored and the term "collective identity" is broadly used to refer to all three.

'Polletta and Jasper's $(2001$, p. 285) otherwise excellent and thorough review of research on identities seems not to distinguish these meanings:

To avoid overextension of the concept, we have defined collective identity as an individual's cognitive, moral, and emotional connection with a broader community, category, practice, or institution. It is a perception of a shared status or relation, which may be imagined rather than experienced directly, and it is distinct from personal identities, although it may form part of a personal identity.

Despite this clear definition equating the term collective identity with the extent of an individual's attachment or relation to a group, their detailed critical review of the ways in which research has used the identity concept to explain movement emergence, recruitment strategy and outcomes gives examples of all three types of identity formation. Similarly, Tilly (1998) uses the term "political identities" in a way that refers largely to individuals and discusses the collective nature of collective identities, but does not clearly demarcate the different levels at which identities are formed.

Individual identities are not necessarily individualist. Social psychologists know that individuals may think of themselves as integrally part of (defined by) some larger group. At the individual level, a movement identity focuses on the extent to which an individual's self-identity includes identification with a movement. Such identities may be referred to as movement identities, activist identities, ethnic or national identities, etc. When actors take on these identities, they merge their sense of self with the larger movement. Their actions cannot be understood in simple cost-benefit terms, but as directed towards preserving and maintaining their identity, their sense of self. Research problems about this kind of identity concern the processes through which individuals come to identify with a broader movement, group, or stance, and the ways such identities influence people's decisions abou their movement participation. The term "identity" in this sense is often used indistinguishably from "solidarity," but the two terms cut differently. To feel solidarity with a group is to have strong positive feelings for and commitment to a group (We discuss the emotional side of identity below.) But identity is about how you see yourself. It would substantially aid clarity if people would not use the term "collective identity" to refer to individuals' views of their relation to a group, but this is probably a vain hope.

Cultural conceptions of identity are found in what Johnston et al. (1994) call collective or public identities. Melucci's (1989) treatment of collective identity refers to the understandings people have about the meaning and purpose of a particular group or movement. For Melucci and others in this tradition, it is important to understand that groups and movements are discursively created in ongoing interaction. Whether a series of events or a set of individuals add up to a movement is discursively created, as is the meaning or purpose of that movement. The idea of the collective identity in this sense is not about the attachment of individuals to the group, but about the nature of the group or movement. Research problems about collective identities in this sense concern the ways they are formed through discursive practices and in ongoing political interaction with other groups and movements. Melucci does not draw the distinction Johnston et al. make between collective and public identities, seeing groups' constructions of themselves as of a piece with their constructions in public, but the distinction seems a useful one. It is useful to think of a group's collective identity construction as impacted by its members' self-constructions on the one hand and the public construction of its identity on the other. Public constructions happen in a discursive space where relatively disembodied ideas interact with other ideas, and are only loosely tied to the self-perceptions of individuals and groups. There is a close, but insufficiently explored, relation between collective identity in this sense and framing (Hunt Benford \& Snow, 1994).

In terms of their relations to structuralist categories, individual identities are especially relevant for understanding why some individuals and not others join and become committed to movements, and why they persist in activism even in 
the face of movement decline (Friedman \& McAdam, 1992; Polletta \& Jasper, 2001). Collective identities are relevant for understanding how groups define their boundaries, goals, strategies, and tactics, and why they rule certain kinds of action in or out of bounds regardless of external judgments of efficacy (Jasper 1997), as well as why they have different definitions of what it means to be a good collectively-oriented member of the group (Lichterman, 1996; Taylor \& Whittier, 1992). Public identities are relevant for understanding how and why groups occupy locations in public political space that are often at variance with their self-perceptions. Clearly understanding the distinction between collective identities and public identities will explain why a particular group of individuals may terminate or abandon one organizational formation and create a new one with a different name and public self-presentation. Ethnic or national identities are public identities, in the sense of defining what it means to be a "Negro" or "good American" or "Muslim" in public discourse.

Of course, public contestations over public identities do not ensure individuals' adoption of these identities into themselves, and groups enact rituals and police boundaries to foster individuals' identification with the group (Berezin, 2001; Taylor \& Whittier, 1992). Individual, collective, and public identities are in constant interaction with one another, but as theory moves forward, it will be increasingly important to maintain distinctions and clarify the relations among them.

\section{Emotions}

Berezin (2001) stresses that identities have an emotional component. Few scholars of social movements defend the binary opposition of emotion and reason, but a full incorporation of emotions into movement theory has lagged the incorporation ideational constructions. As Benford (1997) points out, frame analysts have ignored emotions, thus failing to elaborate on the mediating role that emotions have in the communication and interpretation that goes on among movements and its publics. Older collective behavior theories assumed a discontinuity between rational ordinary behavior and emotional collective behavior, and sought to explain it (see McPhail, 1991, for a review). Social movement theories built in the 1970 s reacted against the "myth of the madding crowd" (McPhail, 1991), denied the alleged discontinuity between individual and collective action, and stressed the rationality and political goals of social movements. Resource mobilization theory assumed rational actors weigh costs and benefits of participation vis-à-vis non-participation, and pursued goal-oriented action constrained and enabled by the availability of resources at their disposal (Jenkins, 1983; McCarthy \&
Zald, 1973, 1977). Political process models focus upon the relations between movements and the state, and generally lack any explicit social psychological model, but tacitly assume rational action and a direct relationship between material conditions and subjective interests. Rationalists recognized hope or "cognitive liberation" (McAdam, 1982) as the probability of making a difference, a necessary component of rational action

Subsequent groups of scholars argued that this lacuna led to distorted theory (see e.g. Goodwin, 1997; Goodwin, Jasper \& Poletta, 2000; Jasper, 1998). The articles collected by Goodwin, Jasper and Polletta (Goodwin et al., 2001) demonstrate the ways in which analyzing emotions can enrich the understanding of social movements. Emotions are pervasive in social movements and play an important role in different points of a movement's life course (Aminzade \& McAdam, 2001). Activists undertaking risky actions have to manage fear (Goodwin \& Pfaff, 2001). Kinship ties and sexuality can disrupt a movement (Goodwin, 1997). Sometimes for instrumental reasons emotions are hidden from the public and only displayed backstage. Robnett (1998) argues that Civil Rights Movement leaders displayed a calm rationality in an instrumental way in order to maintain their legitimacy with the state, while emotions clearly prevailed behind the scenes. Activists around sexual abuse both need to manage their own emotions to maintain their own health, but to manage their public displays of emotion for strategic effect (Whittier, 2001). Public displays of anger make actors look and feel more empowered, but sometimes a display of the fear and pain of victimization is strategically necessary.

Even as emotions are incorporated into social movements theory, that theory has to acknowledge the dichotomization of emotion and reason in much of the larger society. Feminists contend that separating passion and reason not only dichotomizes thought and feeling but also elevates "abstract masculinity" over women's standpoint. Feminist scholars have been vocal critics of the rationalist bias in Western thinking that privileges rational, independent, self-interested action over action that is driven by emotion, undertaken collectively, and motivated by altruism or the desire to affirm the group (Taylor, 1995). Feminist groups try to channel emotions tied to women's subordination (fear, shame, resignation) into emotions conducive to protest (anger). The rationalist bias pervades the culture and affects movements' collective identities. Movements perceived as emotional are often not considered respectable. To gain respectability movement activists may develop a "vocabulary of emotions" to rationalize their participation to others and to themselves. The animal rights activists Groves (1995) studied in the southern United States, reproduced organizationally the dominant gender division of emotion: recruiting men was considered a strategic device to bring credibility to the movement because men were believed less emotional and more rational than women. As a consequence, male activists were often chosen for 
spokesperson and leadership positions while women tended to be overlooked for those positions.

\section{CONCLUSIONS}

Our review has highlighted four important and widespread trends in the study of protest and social movements that should continue. First, "mainstream" theory should continue to address a geographically and substantively broader empirical base, breaking out of a preoccupation with Anglo-America and Europe and becoming truly global in its orientation. This broader base will open new empirical problems that will point to weaknesses in current theory and lead to the development of new theory. Second, social movements theory should continue the tendency to treat "social movements" not as a class of objects, but as a pointer to a class of relationships between non-institutional and institutional political actors. This involves a growing focus on mechanisms and processes that occur in many different movements, and decreasing attempts to develop universal propositions about the causes, effects, or trajectories of whole movements. This theoretical project is currently nascent and unformed. We expect that the final two trends we have identified will contribute to this theoretical project. Event-based studies should continue to grow as one of the best empirical and theoretical approaches for testing and expanding theory focusing on mechanisms and processes. Finally, structuralist and constructivist theories should become integrated. Researchers should spend less time criticizing other approaches for what they did not say, and devote attention to understanding how structures constrain social construction, and how social construction gives meaning to structures. Scholars should recognize the differences between the social psychological and cultural traditions and, thus, be able more explicitly to draw on both as they develop their theories.

Knowledge-building requires a division of labor. A Durkheimian organic solidarity through difference and mutual dependence should be our goal, not agreement on one common theoretical agenda and mode of research. Event-based theory and social constructionist theory are different projects, but both are crucial to the larger complex project of developing better theory for social movements processes. So are many of the smaller streams of work that we have not highlighted in this essay. Practitioners of these different strands of work should follow their own logic, and not seek to pursue one single amorphous agenda. In general, constructionists prefer qualitative research methods, and events researchers quantitative methods. Nevertheless, we believe that each can learn from the other and there are likely to be points of at least partial convergence. There are qualitative researchers focused on events and quantitative researchers focused on the construction of ideas. Both events studies and constructionist studies recognize that a "social movement" is a loosely-bounded phenomenon that changes and evolves in dynamic interaction with other elements in a field. Breaking movements down into events is one possible way to get a research handle on unfolding construction processes. The shifting content of speeches, pamphlets, conversations and other communications can be treated as events, and examined over time. Research is already finding that protest actions interrelate with other forms of public discourse (Koopmans \& Statham, 1999). This does not mean that the two projects can be folded into each other. But it does mean that there is much to be gained from each gaining insights from the other.

Both constructionist projects and events-oriented projects need fully to engage the insights from the first and second trends we noted. That is, they need to be grounded in empirically a truly international terrain of cases and examples, and they need fully to recognize the ways in which the "social movement" is intertwined with institutional politics and other sectors and processes in society. No movement or movement process operates in isolation. Culture, identities, frames and emotions develop and evolve in ongoing interaction with each other and with the "structural" elements of a social system. The cultural or social psychological processes within a movement are never contained wholly within that movement but always draw on developments in other movements and in the larger society. Social movements and protest waves evolve not from their own internal logics, but from the dynamics of their interactions with regimes and news media and their competition with other movements (Oliver \& Myers, 2003a). The challenge of future theorizing is to recognize these complexities without being defeated by them, to find theoretical and methodological strategies for bringing enough order to these complex interactions that we may study them. New theorizing by Oliver and Myers (2003a) and Koopmans (2002) proposes co-evolution as the master paradigm for analyzing these complex interactive relations, but it is too soon to tell whether they have correctly identified the most productive approach.

We end with one comment that arises more from current events than recent scholarship. After the movements of the 1960 s, social protest has come to be seen as a vehicle for democracy, as a tool to be used by the less powerful to accomplish equality- and justice-generating political ends. There are always a few researchers studying hostile or anti-democratic movements, but they have been a minority whose work is rarely mentioned in treatments of general movement theory. In these early years of the 21 st century, we have been repeatedly reminded that protest is not always peaceful and not always tied to pro-democratic tendencies. In this, we may wish to remember the theorists of the 1950s and 1960s, who tried to make sense of totalitarian movements and genocide, and developed the very theories that were 
rejected by the next generation as stigmatizing and psychologizing movement activists. It seems to us that one test of any theory of social movements is that we be able to use the same theory to explain processes in movements we celebrate and those we abhor, or at least to provide a genuinely theoretical account of how they differ. This is not to abandon our duty as citizens to apply moral or ethical standards to judge movements as different, even if we believe their underlying causal mechanisms are the same. But there is a broad tendency to give structural accounts of movements we laud, and psychological accounts of those we disparage. A genuinely integrated theory should be able to explain how movements we consider good and those we consider evil can both arise from the same sets of mechanisms and processes.

\section{NOTES}

1. For good overviews of events, their advantages, and limitations, see Olzak (1989), Rucht and Ohlemacher (1992), Koopmans (1998), and Tarrow (1998), among others.

2. This is a generalization of much more specific critiques. The "resource mobilization" dimension of contemporary theory has been the focal point for the vast majority of these, but the inability of critics to develop an alternative further underscores the more general problem of a "theory/empirical data gap" as described by Koopmans and Rucht. See Turner (1981) Kerbo (1982), Kitschelt (1991), and Goodwin and Jasper (1999) for specific critiques of mainstream social movement theory.

3. Space does not permit a review of either the older psychological traditions or their resource mobilization critics. See Jenkins (1983) for a review of resource mobilization.

4. For example Cohen (1985), Ferree and Miller (1985), Gamson, Fireman and Rytina 4. For example Cohen (1985), Ferree and Miller (1985), Gamson, Fireman and Rytina Miller paper circulated unpublished for year's and influenced and was explicitly credited by McAdam (1982)

\section{REFERENCES}

Alexander, J. C., \& Smith, P. (1993). The discourse of American civil society. Theory and Society, 22, $151-207$

Alexander, J. C., Smith, R., \& Sherwood, S. J. (1993). Risking enchantment. Culture, 8, 10-14.

Alvarez, S. E., Dagnino, E., \& Escobar, A. (Eds) (1998). Cultures of politics - politics of cultures. Boulder: Westview Press

Aminzade, R., \& McAdatn, D. (2001). Emotions and contentious politics. In: R. Aminzade, A. I. Goldstone, D. McAdam, E. J. Perry, W. H. Sewell Jr., S. Tarrow \& C. Tilly (Eds), Silence and Voice in the Study of Contentious Politics (pp. 14-50). New York: Cambridge University Press. Auvinen, J. (1996). IMF intervention and political protest in the third world. Third World Quarterly, $17,377-400$.
Auvinen, J. (1997). Political conflict in less developed countries, 1981m1989. Journal of Peace Research, 34, 177-195

Baierle, S. G. (1998). The explosion of experience. In: S. E. Alvarez, E. Dagnino \& A. Escobar (Eds), Cultures of Politics - Politics of Cultures (pp. 118-138). Boulder: Westview Press.

Beasley-Murray, J. (1999). Learning from Sendero. Journal of Latin American Cultural Studies, 8 $75-88$.

Beissinger, M. R. (1998). Event analysis in transitional societies: Protest mobilization in the former Soviet Union. In: D. Rucht, R. Koopmans \& F. Neidhardt (Eds), Acts of Dissent (pp. 284-316) Berlin: Sigma.

Benford, R. D. (1997). An insider's critique of the social movement framing perspective. Sociological Inquiry, 67, 409-430.

Benford, R. D., \& Snow, D. A. (2000). Framing processes and social movements. Annual Review of Sociology, 26, 611-639.

Berezin, M. (2001). Emotions and political identity. In: J. Goodwin, J. Jasper \& F. Polletta (Eds) Passionate Politics (pp. 83-98). Chicago and London: The University of Chicago Press.

Brysk, A., \& Wise, C. (1997). Liberalization and ethnic conflict in Latin America. Studies in Comparative International Development, 32, 76-104.

Burstein, P. Einwohner, R. L., \& Hollander, J. A. (1995). The success of political movements. In: I. C. Jenkins \& B. Klandermans (Eds), The Politics of Social Protest (pp. 275-295), Minneapolis: University of Mintnesota Press.

Canessa, A. (2000). Contesting hybridity. Journal of Latin American Studies, 32, 115-144.

Cohen, J. L. (1985). Strategy or identity: New theoretical paradigms and contemporary social movements. Social Research, 52, 663-716.

Cook, M. L. (1996). Organizing dissent. Pennsylvania: The Pentsylvania State University Press. Danzger, M. H. (1975). Validating conflict data. American Sociological Review, 40, 570-584.

della Porta, D. (1996). Social movements and the state. In: D. McAdam, J. D. McCarthy \& M. N. Zald (Eds), Comparative Perspectives on Social Movements (pp. 62-92). New York: Cambridge University Press.

della Porta, D. (1999). Protest, protesters, and protest policing. In: M. Giugni, D. McAdam \& C. Tilly (Eds), From Contention to Democracy (pp. 66-96). Boulder: Rowman \& Littlefield.

della Porta, D., \& Reiter, H. (Eds) (1998). Policing protest. Minneapolis: University of Minnesota Press.

Deng, F. (1997). Information gaps and unintended consequences of social movements: The 1989 Chinese student movement. American Journal of Sociology, 102, 1085-1112.

Dwivedi, R. (2001). Environmental movements in the global south. International Sociology, 16, 11-31. Eckstein, S. (1989). Power and popular protest. Berkeley: University of California Press.

Ehrick, C. (1998). Madrinas and missionaries. Gender and History, 10, 406-424.

Einwohner, R. L., Hollander, J. A., \& Olson, T. (2000). Engendering social movements. Gender and Society, 14, 679-699.

Ekiert, G., \& Kubik, J. (1998). Protest event analysis in the study of democratic consolidation in Poland 1989-1993. In: D. Rucht, R. Koopmans \& F. Neidhardt (Eds), Acts of Dissent (pp. 317-348) Berlin: Sigma.

Eliner S. (1999). Obstacles to the consolidation of the Venezuelan neighbourhood movement. Journal of Latin American Studies, 31, 75-97.

Escobar, A. (1992). Culture, economics, and politics in Latin American social movements. In: A Escobar \& S. E. Alvarez (Eds), The Making of Social Movements in Latin America (pp. 62-85) Boulder: Westview Press. 
Escobar, A., \& Alvarez, S. E. (Eds) (1992). The making of social movements in Latin America. Boulder: Westview Press.

Fantasia, R., \& Hirsh, E. L. (1995). Culture in rebellion. In: H. Johnston \& B. Klandermans (Eds), Social Movements and Culture (pp. 144-159). Minneapolis: University of Minnesota Press.

Fernandez Soriano, A., Dilla Alfonso, H., \& Castro Flores, M. (1999). Movimientos comunitarios en Cuba. Estudios Sociologicos, 17, 857-884.

Ferree, M. M., \& Merrill, D. A. (2000). Hot movements, cold cognition. Contemporary Sociology, 29, $454-462$

Ferree, M. M., \& Miller, F. D. (1985). Mobilization and meaning: Toward an integration of social psychological and resource perspectives on social movements. Sociological lnquiry, 55, $38-61$.

Fillieule, O. (1998). 'Plus ça change, moins ça change.' Demonstrations in France during the 1980s. In: D. Rucht, R. Koopmans \& F. Neidhardt (Eds), Acts of Dissent (pp. 199-226). Berlin: Sigma.

Fine, G. A. (1985). Can the circle be unbroken? Small groups and social movements. In: E. Lawler (Ed), Advances in Group Processes (Vol. 2, pp. 1-28). Greenwich: JAI Press.

Fine, G. A. (1995). Public narration and group culture. In: H. Johnston \& B. Klandermans (Eds), Social Movements and Culture (pp. 127-143). Minneapolis: University of Minnesota Press.

Foweraker J. (1995). Theorizing social movements. London: Pluto Press.

Foweraker, J., \& Craig, A. L. (Eds) (1990). Popular movements and political change in Mexico. Boulder Lynne Rienner.

Franzosi, R. (1987). The press as a source of socio-historical data. Historical Methods, 20, 5-16.

Friedman, D., \& McAdam, D. (1992). Collective identity and activism. In: A. D. Morris \& C. M. Mueller (Eds), Frontiers in Social Movement Theory (pp. 156-173). New Haven: Yale University Press.

Gamson, W. A. (1975). The strategy of social protest. Homewood: Dorsey.

Gamson, W. A. (1990). The strategy of social protest (2nd ed.). Belmont: Wadsworth.

Gamson, W. A.. Fireman, B., \& Rytina, S. (1982). Encounters with unjust authorities. Homewood Dorsey Press.

Gentile, P. (1998). Radical right protest in Switzerland. In: D. Rucht, R. Koopmans \& F Neidhard (Eds), Acts of Dissent (pp. 227-252). Berlin: Sigma

Gill, A. (1999). Government regulation, social anomie and Protestant growth in Latin America. Ratio nality and Society, $11,287-316$

Gitugni, M. (1998). Was it worth the effort? Annual Review of Sociology, 24, 293-371.

Giugni, M. (1999). How social movernents matter. In: M. Giugni, D. McAdam \& C. Tilly (Eds), How Social Movements Matter (pp. xiii-xxxiii). Minneapolis: University of Minnesota Press.

Goldstone, J. A. (1998). Social movements or revolutions? In: M. Giugni, D. McAdam \& C. Tilly (Eds), How Social Movements Matter (pp. 125-145). Minneapolis: University of Minnesota Press.

Goldstone, J. A. (Ed.) (2002). States, parties, and social movements. New York: Cambridge University Press.

Goodwin, J. (1997). The Libidinal constitution of a high-risk social movement. American Sociological Review, 62, 53-69.

Goodwin, J. \& Jasper, J. (1999). Caught in a winding, snarling vine: The structural bias of political process theory. Sociological Forum, 14, 27-54.

Goodwin, J., Jasper, J., \& Polletta, F. (2000). Return of the repressed. Mobilization, 5, 65-84.

Goodwin, J., Jasper, J., \& Polletta, F. (Eds) (2001). Passionate politics. Chicago and London: The University of Chicago Press.
Goodwin, J., \& Pfaff, S. (2001). Emotion work in high-risk social movements. In: J. Goodwin, J. Jasper \& F. Polletta (Eds), Passionate Politics (pp. 282-300). Chicago and London: The University of Chicago Press.

Groves, J. M. (1995). Learning to feel. The Sociological Review, 43, 435-461.

Guidry, J. A., Kennedy, M. D., \& Zald, M. N. (Eds) (2000). Globalizations and social movements. Ann Arbor: University of Michigan Press.

Gusfield, J. (1981). Drinking-driving and the symbolic order. Chicago: University of Chicago Press. Guy, D. J. (1998). The politics of Pan-American cooperation. Gender and History, 10, 449-469.

Hipsher, P. L. (1996). Democratization and the decline of urban social movements in Chile and Spain. Comparative Politics, 28, 273-297.

Hipsher, P. L. (1998a). Democratic transitions and social movement outcomes. In: M. Giugni, D. McAdam \& C. Tilly (Eds), From Contention to Democracy (pp. 149-167). Boulder: Rowman \& Littlefield.

Hipsher, P. L. (1998b). Democratic transitions as protest cycles. In: D. S. Meyer \& S. Tarrow (Eds), The Social Movement Society (pp. 153-172). Oxford: Rowman \& Littlefield.

Hocke, P. (1998). Determining the selection bias in local and national newspaper reports on protest events. In: D. Rucht, R. Koopmans \& F. Neidhardt (Eds), Acts of Dissent (pp. 131-163). Berlin: Sigma.

Huiskamp, G. (2000). Identity politics and democratic transitions in Latin America. Theory and Society, $29,385-424$.

Hunt, L. (1984). Politics, culture, and class in the French Revolution. Berkeley: University of California Press.

Hunt, S. A., Benford, R. D., \& Snow, D. A. (1994). Identity fields. In: E. Laraña, H. Johnston \& J. R. Gusfield (Eds), New Social Movements (pp. 184-208). Minneapolis: University of Minnesota Press.

Jackman, R. W., \& Boyd, W. A. (1979). Multiple sources in the collection of data on political conflict. American Journal of Political Science, 23, 434-458.

Jaquette, J. S. (Ed.) (1994). The women's movement in Latin America: Participation and democracy (2nd ed.). Boulder: Westview Press.

Jasper, J. (1997). The art of moral protest. Chicago: The University of Chicago Press.

Jasper, J. (1998). The emotions of protest. Sociological Forum, 13, 397-424.

Jelin, E. (2001). Cultural movements and social actors in the new regional scenarios. International Political Science Review, 22, 85-98.

Jelin, E. Zammit, J. A., \& Thomson, M. (1990). Women and social change in Latin America. Geneva: Zed Books.

Jenkins, C. (1983). Resource mobilization theory and the study of social movements. Annual Review of Sociology, 9, 527-553.

Johnston, H., Laraña, E.. \& Gusfield, J. R. (1994). Identities, grievances, and new social movements. In: E. Laraña, H. Johnston \& J. R. Gusfield (Eds), New Social Movements (pp. 3-36). Minneapolis: University of Minnesota Press.

Kay, C. (1998). El fin de la reforma agraria en America Latina? Revista Mexicana de Sociologia, 60, $63-98$.

Keck M. E. \& Sikkink, K. (1998). Activists beyond borders. Ithaca, NY; Comell UP.

Kerbo, H. R. (1982). Movements of 'crisis' and movements of 'affluence'. Journal of Confict Resolution, 26, 633-645.

Kerbo, H. R., \& Shaffer, R. A. (1992). Lower class insurgency and the political process. Social Problems, 39, 139-154 
Khawaja, M. (1994). Resource mobilization, hardship, and popular collective action in the West Bank Social Forces, 73, 191-220.

Khawaja, M. (1995). The dynamics of 1ocal collective action in the West Bank. Economic Development and Cultural Change, 44, 147-179.

Kitschelt, H. (1991). Resource mobilization theory: A critique. In: D. Rucht (Ed.), Research on Social Movements. Boulder: Westview.

Klandermans, B. (1984). Mobilization and participation. American Sociological Review, 49, 583-600. Koopmans, R. (1993). The dynamics of protest waves. American Sociological Review, 58, 637-658. Kooptnans, R. (1996). New social movements and changes in political participation in Western Europe. West European Politics, 19, 28-50.

Koopmans, R. (1998). The use of protest event data in comparative research. In: D. Rucht, R. Koopman \& E Neidhardt (Eds), Acts of Dissent (pp. 90-110). Berlin: Sigma

Koopmans, R. (2002). Protest in time and space. In: D. A. Snow et al. (Eds), The Blackwell Companion to Social Movements. Oxford: Blackwell.

Koopmans, R., \& Rucht, D. (1999). Protest event analysis - Where to now? Mobilization, 4, 123-130.

Koopmans, R., \& Statham, P. (1999). Ethnic and civic conceptions of nationhood and the differentia success of the extreme right in Germany and Italy. In: M. Giugni, D. McAdam \& C. Tilly (Eds) How Social Movements Matter (pp. 225-251). Minneapolis: University of Minnesota Press.

Kriesi, H., Koopmans, R., Duyvendak, J. W., \& Giugni, M. G. (1992). New social movements and political opportunities in Western Europe. European Journal of Political Research, 22 219-244.

Kriesi, H., Koopmans, R., Duyvendak, J. W. \& Giugni, M. G. (Eds) (1995). New social movements in Western Europe. Minneapolis: University of Minnesota Press.

Larroa Torres, R. M. (1997). El papel del campesinado en la reforma agraria y la definicion de las politicas agrarias de America Latina. Estudios Latinoamericanos, 4, 93-107.

Le Bot, Y. (1999). Churches, sects and communities. Bulletin of Latin American Research, 18, 165-174. Lichterman, P. (1996). The search for political community. New York: Cambridge University Press.

Linz, J. J., \& Stepan, A. (1996). Problems of democratic transition and consolidation. Baltimore: The Johns Hopkins University Press.

López Jiménez, A. (1996). Politica y religion en America Latina. Politica y sociedad, 22, 91-101.

Macy, M. W. (1990). Learning theory and the logic of critical mass. American Sociological Review, $55,809-826$

Mainwaring, S. (1987). Urban popular movements, identity and democratization in Brazil. Comparative Politics, $21,131-159$

Mainwaring, S. (1989). Grassroots popular movements and the struggle for democracy: Nova Iguacu. In: A. Stepan (Ed.), Democratizing Brazil (pp. 168-204). New York: Oxford University Press.

Mainwaring, S. \& Viola, E. (1984). New social movements, political culture, and democracy. Telos, $61,17-52$.

Maney, G. M., \& Oliver, P. E. (2001). Finding event records. Sociological Methods and Research, 29 $131-169$.

Mascott, M. A. (1997). Cultural politica y nuevos movimientos sociales en America Latina. Metapolitica, 1, 227-239.

Massolo, A. (1999). Defender y cambiar la vida. Mujeres en movimientos populares urbanos. Cuicuilco, $6,13-23$.

Mato, D. (2000). Transnational networking and the social production of representations of identities by indigenous peoples' organizations of Latin America. International Sociology, 15 , $343-360$.
McAdam, D. (1982). Political process and the development of black insurgency: 1930-1970. Chicago: University of Chicago Press.

McAdam, D. (1983). Tactical innovation and the pace of insurgency. American Sociological Review, $48,735-754$

McAdam, D. (1988). Freedom Summer. New York: Oxford University Press.

McAdam, D. (1994). Culture and social movements. In: E Laraña, H. Johnston \& J. R. Gusfield (Eds), New Social Movements (pp. 36-57). Philadelphia: Temple University Press.

McAdam, D., McCarthy, J. D., \& Zald, M. N. (Eds) (1996). Comparative perspectives on socid movements. New York: Cambridge University Press.

McAdam, D., Tarrow, S., \& Tilly, C. (2001). Dynamics of contention. New York: Cambridge University Press.

McCammon, H. J. Campbell, K. E Granberg, E. M \& Mowery, C. (2001). How movements win. American Sociological Review, 66, 49-70.

McCarthy J. D. McPhail C \& Smith, J. (1996). Images of protest. American Sociological Review, $61,478-499$.

McCarthy, J. D., McPhail, C., Smith, J., \& Crishock, L. J. (1998). Electronic and print media representations of Washington, DC demonstrations, 1982 and 1991. In: D. Rucht, R. Koopmans \& F. Neidhardt (Eds), Acts of Dissent (pp. 113-130). Berlin: Sigma.

McCarthy, J. D., \& Zald, M. N. (1973). The trend of social movements in America. Morristown: General Learning Press.

McCarthy, J.D., \& Zald, M. N. (1977). Resource mobilization and social movements. American Journal of Sociology, 82, 1212-1242.

McPhail, C. (1991). The myth of the madding crowd. New York: Aldine de Gruyter.

McPhail, C., Schweingruber, D., \& McCarthy, J. D. (1998). Policing of protest in the United States, 1960 1995. In: D. della Porta \& H. Reiter (Eds), Policing Protest (pp. 49-69). Minneapolis University of Minnesota Press.

Melucci, A. (1985). The symbolic challenge of contemporary movements. Social Research, 52, $789-816$.

Melucci, A. (1989). Nomads of the present. Philadelphia: Temple University Press.

Melucci, A., \& Lyyra, T. (1998). Collective action, change and democracy. In: M. Giugni, D. McAdam \& C. Tilly (Eds), From Contention to Democracy (pp. 203-227). Boulder: Rowman \& Littlefield. Merton, R. K. (1948). The self-fulfilling prophecy. Antioch Review, 193-210.

Meyex, D. S., \& Whittier, N. (1994). Social movement spillover. Social Problems, 41, 277-298.

Misztal, B., \& Shupe, A. (1998). Fundamentalism and globalization. In: A. Shupe \& B. Misztal (Eds), Religion, Mobilization, and Social Action (pp. 3-14). Westport, CT: Praeger.

Morris, A. D. (1984). The origins of the civil rights movement. New York: Free Press.

Mosse, G. (1975), The nationalization of the masses. New York: H. Fertig.

Mueller C (1997). Media measurement models of protest event data Mobilization, 2, 165-184.

Mueller, C. (1999). Claim "radicalization?". Social Problems, 46, 528-547.

Myers, D. J. (1997). Racial rioting in the 1960s. American Sociological Review, 62, 94-112

Myers, D. J. (2000). The diffusion of collective violence. American Journal of Sociology, 106, 173-208.

Myers, D. J., \& Buoye, A. J. (2001). Campus racial disorders and community ties, 1967-1969. Research in Social Movements, Conficts and Change, 23, 297-327.

Oliver, P. E. (1989). Bringing the crowd back in. In: L. Kriesberg (Ed.), Research in Social Movements, Confict and Change (Vol. 11, pp. 1-30). Greenwich: JAI Press.

Oliver, P. E., \& Johnston, H. (2000). What a good idea! Ideologies and frames in social movement research. Mobilization, 5, 37-54. 
Oliver, P. E., \& Maney, G. M. (2000). Political processes and local newspaper coverage of protest events. American Journal of Sociology, 106, 463-505.

Oliver, P. E., \& Myers, D. J. (1999). How events enter the public sphere. American Journal of Sociology, $105,38-87$.

Oliver, P. E., \& Myers, D. J. (2003a). The co-evolution of social movements. Mobilization.

Oliver, P. E., \& Myers, D. J. (2003b). Networks, diffusion, and cycles of collective action. In: M. Diani \& D. McAdan (Eds), Social Movement Analysis. New York: Oxford University Press.

Olzak, S. (1987). Causes of ethnic conflict and protest in urban America, 1877-1889. Social Science Research, 16, 185-210.

Olzak, S. (1989). Analysis of events in the study of collective action. Annual Review of Sociology, 15, 119-141.

Oizak, S. (1992). The dynamics of ethnic competition and conflict. Stanford: Stanford University Press.

Oxhorn, P. D. (1995). Organizing civil society. Pennsylvania: The University of Pennsylvania Press.

Petras, J., \& Veltmeyer, H. (2001). Are Latin American peasant movements still a force for change? Journal of Peasant Studies, 28, 83-118.

Polletta, F. (1997). Culture and its discontents. Social Inquiry, 67, 431 -450

Polletta, F., \& Jasper, J. (2001). Collective identity and social movements. Annual Review of Sociology, $27,283-305$.

Rasler, K. (1996). Concessions, repression and political protest in the Iranian revolution. American Sociological Review, $61,132-152$

Robnett, B. (1998). African American women in the civil rights movement. In: K. M. Blee (Ed.), No Middle Ground. Women and Radical Protest (pp. 65-95). New York: New York University Press.

Rubin, J. (1998). Ambiguity and contradiction in a radical popular movement. In: S. E. Alvarez, E. Dagnino \& A. Escobar (Eds), Cultures of Politics - Politics of Cultures (pp. 141-164). Boulder: Westview Press.

Rucht, D. (1996). Recent right-wing radicalism in Germany. Research on Democracy and Society, 3, $255-274$.

Rucht, D., \& Neidhardt, F. (1998). Methodological issues in collecting protest event data. In: D. Rucht, R. Koopmans \& F. Neidhardt (Eds), Acts of Dissent (pp. 65-89). Berlin: Sigma.

Rucht, D., \& Ohlemacher. (1992). Protest event data. In: M. Diani \& R. Eyerman (Eds), Studying Collective Action. London: Sage.

Safa, H. I. (1996). Beijing, diversity and globalization. Organization, 3, 563-570.

Sandoval S. A. M. (1998) Social movements and democratization. In: M. Giugni, D. McAdam \& C. Tilly (Eds), From Contention to Democracy (pp. 169-201). Boulder: Rowman \& Littlefield.

Schild, V. (1997). New subjects of rights? Gendered citizenship and the contradictory legacies of social movements in Latin America. Organization, 4, 604-619.

Schneider, C. L. (1995). Shantytown protest in Pinochet's Chile. Philadelphia: Temple University Press. Schneider, C. L. (2000). Violence, identity and spaces of contention in Chile, Argentina and Colombia. Social Research, 67, 773-802.

Scott, J. C. (1990). Domination and the arts of resistance. New Haven: Yale University Press.

Sewell, W. H., Jr. (1996). Three temporalities. In: T. J. McDonald (Ed.), The Historic Turn in the Human Sciences (pp. 245-280). Ann Arbor: University of Michigan Press.

Sewell, W. H., Jr. (1999). The concept(s) of culture. In: V. Bonnell \& L. Hunt (Eds), Beyond the Cultural Turn (pp. 35-61). Berkeley: University of California Press.

Smith, J. (2001). Globalizing resistance. Mobilization, 6, 1-19.
Smith, J. G., Chatfeld, C., \& Pagnucco, R. (Eds) (1997). Transnationat social movements and global politics. Syracuse, NY: Syracuse University Press.

Snow, D. A., \& Benford, R. (1988). Ideology, frame resonance, and participant mobilization. In: B. Klandermans, H. Kriesi \& S. Tarrow (Eds), From Structure to Action (Vol. 1, pp. 197-217) Greenwich: JAI Press.

Snow, D. A., \& Bentord, R. (1992). Master frames and cycles of protest. In: A. D. Morris \& C M. Mueller (Eds), Frontiers in Social Movement Theory (pp. 133-155). New Haven: Yale University Press.

Snow, D. A., Rochford, E. B., Jr., Worden, S. K., \& Benford, R. D. (1986). Frame alignment processes, micromobilization, and movement participationl. American Sociological Review, 51, 464-481.

Snyder, D., \& Kelly, W. R. (1977). Conflict intensity, media sensitivity and the validity of newspaper data. American Sociological Review, 42, 105-123.

Soule, S. A. (1997). The student divestment movement in the United States and tactical diffusion. Social Forces, 75, 855-882.

Soule, S. A. (1999). The diffusion of an unsuccesstul innovation. Annals of the American Academy of Political and Social Science, 566, 120-131

Soule, S. A., McAdam, D., McCarthy, J., \& Su, Y. (1999). Protest events: Cause or consequence of state action? Mobilization, 4, 239-255.

Soule, S. A., \& Zylan, Y. Z. (1997). Runaway train? American Journal of Sociology, 103, 733-762. Stokes, S. C. (1995). Cultures in confict. Berkeley: University of California Press.

Stonich, S. C., \& Bailey, C. (2000). Resisting the blue revolution. Human Organization, 59, 23-36.

Swidier, A. (1986). Culture in action, symbols and strategies. American Sociological Review, 51 , 273-286.

Szabo, M. (1996). Repertoires of contention in post-communist protest cultures. Social Research, 63 $1155-1182$.

Tarrow, S. (1998). Studying contentious politics. In: D. Rucht, R. Koopmans \& F. Neidhardt (Eds), Acts of Dissent (pp. 33-64). Berlin: Sigma.

Taylor, V. (1995). Watching for vibes. In: M. M. Ferree \& P. Y. Martin (Eds), Feminist Organizations Harvest of the New Women's Movement (pp. 223-233). Philadelphia: Temple University Press.

Taylor, V., \& Whittier, N. E. (1992). Collective identity in social movement communities. In: A. D. Morris \& C. M. Mueller (Eds), Frontiers in Social Movement Theory (pp. 104-129). New Haven: Yale University Press.

Thomas, W. 1., \& Thomas, D. S. (1928). The child in America. New York: Knopf.

Tilly, C. (1978). From mobilization to revolution. Reading: Addison-Wesley.

Tilly, C. (1995). Popular contention in Great Britain, 1758-1834. Cambridge, MA. Harvard University Press.

Tilly, C. (1998). Political identities. In: M. P. Hanagan, L. P. Moch \& W. T. Brake (Eds), Challenging Authority (pp. 3-16). Minneapolis: University of Minnesota Press.

Tilly, C. (1999). From interactions to outcomes in social movements. In: M. Giugni, D. McAdam \& C. Tilly (Eds), How Social Movements Matter (pp. 253-270). Minneapolis: University of Minnesota Press.

Turner, R. (1981). Collective behavior and resource mobilization as approaches to social movements. Research in Social Movements, Conflict, and Change, 4, 1-24.

Turner, R. (1983). Figure and ground in the analysis of social movements. Symbolic Interaction, 6 175-181.

Veltmeyer, H. (1997). New social movements in Latinl America. Journal of Peasant Studies, 25, 139-169. 
Walton, J. (1989). Debt protest and the state in Latin America. In: S. Eckstein (Ed.), Power and Popular Protest (pp. 299-328). Berkeley: University of California Press.

Walton $J$ \& Ragin $C(1990)$ Giobal and national sources of political protest: Third world responses to the debt crisis. American Sociological Review, 55, 876-890.

Waiton, J., \& Seddon, D. (1994). Free markets and food riots. Oxford: Blackwell.

Whittier, N. (2001), Emotional strategies. In: J. Goodwin, J. Jasper \& F. Polletta (Eds), Passionate Politics (pp. 233-250). Chicago and London: The University of Chicago Press.

Williams, H. L. (1996). Planting trouble. San Diego: University of California-San Diego.

Tamorano Farías, R. (1999). Dilemas politicos sobre los movimientos socials. Revista Mexicana de Sociologia, 61, 201-232.

\section{QUALITATIVE RESEARCH ON SOCIAL MOVEMENTS: EXPLORING THE ROLE OF QUALITATIVE DESIGNS IN EXAMINING CONTENTIOUS POLITICAL ACTION}

\author{
Timothy B. Gongaware and Robert D. Benford
}

\begin{abstract}
The proliferation of social movements and their growing importance has spawned an expansion of scholarship on collective action. Recent social psychological, cultural and narrative shifts in movement research have yielded a resurgence in the use of qualitative methods to study such contentious politics. The bulk of the research questions contemporary movement scholars currently pose warrant qualitative designs. These questions, many of which were first posed by the second Chicago school collective behavior scholars decades before, include questions of interpretive frameworks, culture, identities, narratives, other group processes and structures. We review the various qualitative techniques social movement scholars currently employ, highlight their relevance to the constructivist project and speculate on the future of qualitative methods in addressing questions pertaining to globalization, framing processes, collective identities, narratives and emotions.
\end{abstract}

Political Sociology for the 21st Century

Research in Political Sociology, Volume 12, 245-281

Copyright $\odot 2003$ by Elsevier Science Ltd.

All rights of reproduction in any form reserved

ISSN: 0895-9935/PII: S0895993503120104 